
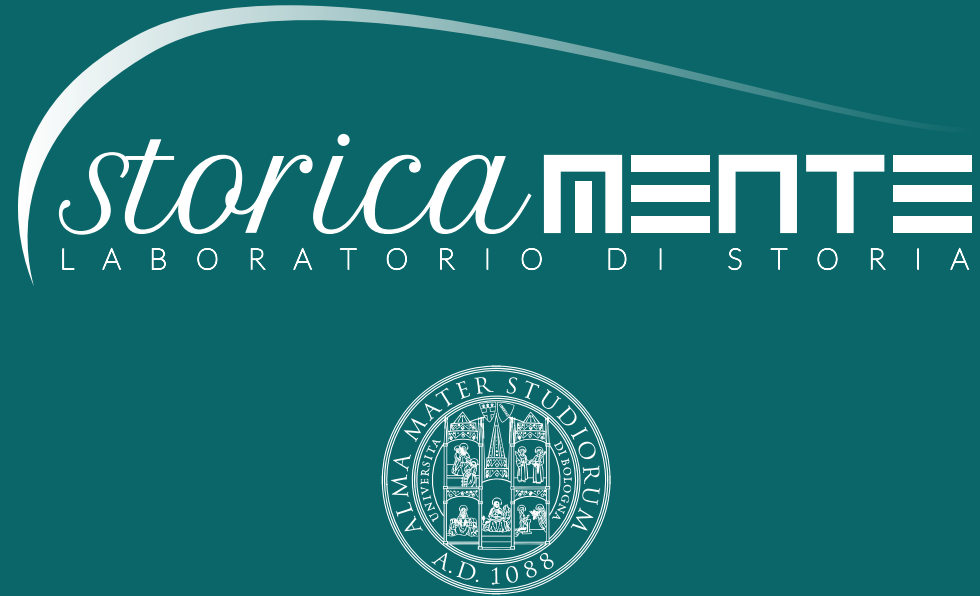

ALMA MATER STUDIORUM

Università di Bologna

Dipartimento di Storia Culture Civiltà

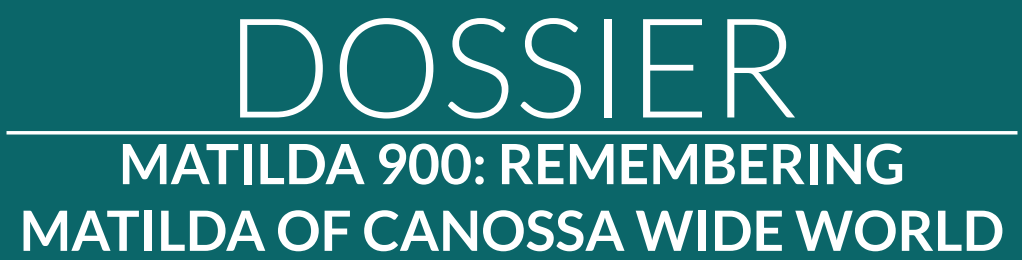




\section{STORICAMENTE.ORG}

\section{Laboratorio di Storia}

Valerie Eads, Tiziana Lazzari

Raising Matilda from the Footnotes

Numero 13 - 2017

ISSN: 1825-411X

Art. 12

pp. 1-10

DOI: $10.12977 /$ stor672

Editore: BraDypUS

Data di pubblicazione: 22/08/2017

Sezione: Dossier: "Matilda 900: Remembering Matilda of Canossa Wide World" 


\title{
Raising Matilda from the Footnotes
}

\author{
VALERIE EADS, TIZIANA LAZZARI \\ School of Visual Art, New York \\ Univ. Bologna, Dipartimento di Storia Culture Civiltà
}

In 2015, in order to commemorate the ninth centennial of the death of the Great Countess Matilda of Canossa, four sessions and a roundtable discussion were organized under the rubric Matilda 900. These sessions took place at the 50th International Congress on Medieval Studies (University of Western Michigan, Kalamazoo, MI) in the US and the Leeds International Medieval Congress (University of Leeds) in the UK. Papers were read by scholars from Australia, Canada, Ireland, Italy, the UK and the USA. The Kalamazoo Congress is the world's largest gathering of scholars of the Middle Ages, and, although a number of papers were read over the years, there had been no session devoted to Matilda in the previous thirty years, if ever. The Leeds Congress attracts more participants from European countries, but the sessions held at the 2015 conference were the first devoted to Matilda, as nearly as could be determined. Thus, a major goal of Matilda 900 was to ensure that the Great Countess' ninth centennial did not pass without notice alongside the commemorations of Azincourt (1415), Magna Carta (1215) and the Fourth Lateran Council (1215), events that are much better known in English-language scholarship. It is especially gratifying that scholars 
from Italy joined the sessions.

Among the functions of centennial commemorations, a staple of scholarly communication since the mid-nineteenth century, is to provide an opportunity for scholars working on a single person or event to report the status quaestionis, to present recent and ongoing work, and to set out plans for future projects. These centennial sessions had the further aim of presenting the figure of Matilda of Canossa to a larger scholarly community. Indeed, despite considerable activity in such areas as gender, feminist studies, female lordship and military history - along with studies in medievalism that could find the countess' extensive Nachleben of considerable interest - the standard English-language biographies of Matilda remain what they were when the eighth centennial of her death was marked in 1915, as World War I raged.

While the men in her life, Pope Gregory VII and Emperor Henry IV, have found their biographers, Matilda has not?. The only English-language monograph on Matilda published in the eight succeeding decades of the twentieth century was Robert Hollister Rough's study of the Matilda Gospel, an illustrated work presented by Matilda to San Benedetto Po in the late eleventh century, now residing in the Morgan Library in New York (the Library did not see fit to mark Matilda's ninth centennial in any way because "we already exhibited the Matilda Gospels a few years ago as part of our East Room rotations, and it is too soon to show it again»') [Rough 1973]. The twenty-first century saw the first overview of Matilda's entire military career, David Hay's study of Matilda as a military leadert. If the survey of the literature is

See Duff 1909; Huddy 1906 and Nell'VIII centenario di Matilde 1915.

See Cowdrey 1998; Robinson 1999. Indeed, popular readers may be ahead of scholars as far as Matilda is concerned thanks to an adroit and very readable mix of biography, travel guide and novel, see Spike 2004.

3 Email from William Voelkle, Curator of Medieval and Renaissance Manuscripts at The Morgan Library, April 25, 2014.

4 See Rough 1973; Hay 2008. 
expanded to include articles devoted to Matilda, the countess has only a slightly larger footprint in anglophone scholarship ${ }^{5}$.

Matilda has not, of course, been entirely left out. The biographies of Pope Gregory VII and Emperor Henry IV perforce include much about Matilda, but only as her actions relate to the men who are the subject of those works. Matilda figures prominently in works treating such topics as the polemic of the Investiture Controversy, a significant portion of which originated in her circle, or the life and work of Abbot Desiderius of Montecassino whom Matilda supported as Pope Victor III, as well as the influence, or lack thereof, of Matilda in art history ${ }^{6}$. While Matilda is not a stranger in articles treating a range of topics, the countess has a lesser presence on the larger stage [Bisson 2000, 101-113].

In feminist and gender studies, it has been recognized that if each politically powerful and militarily effective woman is treated as somehow exceptional, a sample of one, the inclusion of even intensely-studied women in the broader historical narrative is inhibited, and some of the papers published here note that Matilda of Canossa has suffered from being treated as sui generis [Lo Prete 2014, 55-110]. A number of women relatively close to Matilda in time and status - Adela, countess of Blois; Ermengarde, viscountess of Narbonne and Matilda's second mother-in-law, Judith of Flanders, Duchess of Bavaria - have found their biographers in the twenty-first century? It seems that, as far as English-language scholarship is concerned, Matilda's presence is recognized, but hers is a supporting rather than a leading role.

The situation is completely different in the historiography of the European continent where studies of Matilda and the Canossans, especially in the work of Italian and German and, most recently, of French re-

See Reynolds 2002, 1-13; Healy 2005, 49-56; Eads 2010, 23-68; Verzar 2010, 7390.

6 See Robinson 1978; Cowdrey 1983; Glass 2010.

See Cheyette 2001; Lo Prete 2007; Dockray 2015. 
searchers, has resulted in a large output that has been consistent over time, with some peaks in particular circumstances. This would include, of course, 2015, when the International Center for Studies on the Early Middle Ages (CISAM) in Spoleto organized an entire meeting dedicated to Matilda and her times. On some occasions, anniversaries seem skillfully multiplied to have a pretext to take up again a theme that still sustains a lively interest. Matilda and her times is, however, a topic that is very popular, even with a non-academic public, as the success of the exhibitions that have been mounted over the past ten years on this subject, accompanied by catalogs that collect sometimes very technical specialist contributions, shows ${ }^{9}$. But, the circulation of this work is largely limited to specialized historiographical circuits that only rarely confront each other. The first, in order of isolation, is undoubtedly the local historiography that has long seen Matilda as a sort of tutelary deity, the undisputed heroine of the landscape, of religiosity and of numerous popular traditions of the Po Valley and Apennine territories, comprising the present day provinces of Reggio Emilia, Modena, Mantua and Ferrara ${ }^{10}$. The second circuit, then, deals with studies of the forms of power and the organization of the territory of the Italian kingdom from the tenth to twelfth centuries. This is a research field that, over fifty years of an almost exclusively Italian historiographic tradition, has achieved results of great interpretative refinement, but which finds, unfortunately, a decidedly marginal response in other historiographies"

The proceedings of the four-day conference are published in Matilde di Canossa e il suo tempo 2016.

See Stiegemann, Wemhoff 2006; Calzona 2008; Salvarani, Castelfranchi 2008; Golinelli 2008.

10 It is impossible to cite here a title summarizing the truly vast local historiographic production; for a systematic account with a very full bibliography see Rinaldi 2003.

11 The fortunes of Matilda and the Canossa are framed in the most general context of the political history of the kingdom of Italy in the tenth and eleventh centuries by Sergi 1995 and by Cammarosano 1998. 
Finally, the third is the circuit of studies linked to the reform of the Church in the eleventh century, in which Matilda is surely seen among the protagonists. And that, despite the inevitable universality of the theme, is precisely the context in which the difficult communication between the historiographies of different languages and traditions is most evident. Starting from the fundamental Italian historiography of the 1960s and 1970s, mainly represented by Ovidio Capitani and Giovanni Miccoli and their schools, it is inconceivable in the Italian academic context to use such an expression as "Gregorian reform», which, along with its interpretive assumptions, is still quite strong in English and French historiography."

Recent years have seen some research approach the theme of Matilda and the Canossa according to fresh perspectives which focus on either the iconographic and textual analysis of the sources most directly related to her political and personal action, taking into account the symbolic readings of power and of its communication ${ }^{13}$, or on her family ties and her role in the context of the thematic perspectives on family structures ${ }^{14}$ and also on the political role of women ${ }^{15}$ opened by gender studies, albeit with results that do not always converge. Regarding the established historiographic traditions, these studies have attempted a combining of themes and a larger sharing of the works of national historiographies based on a blending of research rather than on language. It is clear to both editors, however, that reciprocal communication among the various historiographic traditions, especially the Anglo-Saxon, really needs a linguistic vehicle, English. It is for this reason that we have chosen to publish this collection of works in English,

\footnotetext{
Among the very numerous works of Ovidio Capitani, we need to mention at least: Capitani 1966; 1984; 1990; Miccoli 1966.

13 See Lazzari 2006, 57-92 and Golinelli 2003.

14 See Le Jan 2009, 105-120 and Lazzari 2012, 225-242.

15 See Lazzari 2016, 35-55; Le Jan, in press.
} 
but in an Italian journal and edited by two hands, a choice that should be interpreted, therefore, as a concrete attempt to open a constructive dialogue between historiographies that still face great difficulties in working with and even knowing one another.

The papers and comments presented here are a mix of old and new, of traditional and revisionist. John Dempsey revisits the time-honored topic of Matilda as ecclesiastical patron, but with the aim of showing that, while she consistently supported reformers, her policy could include a broad range of ideological positions and was always consistent with her political and strategic goals as well as her ideological agenda. Alison Creber's study returns to Canossa with the goal of foregrounding the role of the elite women who, along with Matilda, exercised their intercessory and mediatory functions, a decidedly updated view of an event which has heretofore been presented largely in terms of the male protagonists, Henry IV and Gregory VII, although neither came to Canossa alone.

Eugenio Riversi explores an equally venerable topic, that of the relations between Matilda and the cities in her domain, using a configurational and comparative analysis that brings multiple agents into play and questions the traditional historiographical view of a confrontational dyad when interpreting the emergence of the Italian city communes.

Donizone of Canossa's Vita Mathildis has been read and re-read many times since it was first published in the sixteenth century, and no fewer than three of these papers return to that source. The digital publication of the original manuscript has allowed David Hay to examine the marginalia and to determine that they hold the clue to clarifying Donizone's account of an armed encounter at Tricontai in the Veneto (1091), an engagement that resulted in a grave defeat for Matilda's troops, while Robert Houghton finds that Donizone's influence has distorted the perception of the relationship between the emperor Conrad II and Matilda's father, Marquis Bonifacio. Francesca Guerri examines Donizone alongside the vitae of Anselm II of Lucca to explore the relationship 
between Matilda and her spiritual guide and to evaluate Anselm's influence on her political and religious program.

The renewed consideration of Matilda's family continues with Tiziana Lazzari's analysis of the sarcophagus of Beatrice of Lorraine, a secondcentury representation of the legend of Phaedra and Hippolytus, surely a disturbing topic for Matilda to select for her mother's tomb. Giorgio Milanesi's analysis of the comparative roles of the bishops and of Matilda's family in the long history and numerous rebuildings of the Romanesque cathedral of Reggio Emilia extends the reconsideration of physical resources.

As to what the future holds, the roundtable discussion, "The Gregorian Reform and Beyond," presents a similar mix of traditional and revisionist. Edward Coleman suggests revisiting the topic of the communes to compare again the reactions of Matilda and of Henry IV and Henry $\mathrm{V}$ and to consider that Matilda's support of church reform facilitated the rise of the communes. Valerie Eads revives a suggestion first made thirty years ago, i.e., flipping the exceptional woman paradigm to consider that the assumption that women could perform military functions is built into the male-normative view of medieval warfare. This would require feminist scholars to engage more fully with the practicalities of warfare. Eads finds that, even though gender studies and feminist scholarship have shown great interest in female lordship and agency, there remains a decided scholarly bias that favors the image over the amazon. David Hay reexamines a central question, "Are we overestimating the influence of Matilda?" and presents a number of issues that need to be reconsidered. The investigation would incorporate a combination of new technology, computer modeling, with old-fashioned archaeology. Robert Houghton raises a number of the same points, but extends the discussion to the other Canossans and to the pro-reform episcopacy as well. In this view, Matilda is in danger of becoming an almost stock figure precisely because she has been much-studied. The proposed steps include a more careful re-reading of the known sources and a more 
thorough examination of relatively neglected sources such as charters, including those other than Matilda's, to redress some of the inaccuracies of the narrative sources. Penelope Nash discusses the changing fortunes of Matilda over the ages and presents a number of reasons why she is neglected in anglophone scholarship, as compared, for example, to Joan of Arc, but Nash also considers that Donizone may be more reliable than the previous speakers suggest.

Based on these observations, we can look forward to a wave a continuing interest in Matilda of Canossa among anglophone scholars, present and future, which will include both some fine old wine in new bottles and a few stylish old bottles holding a young vintage of scholarship.

\section{Bibliography}

Bisson T.N. 2000, Princely Nobility in an Age of Ambition (c. 1050-1150), in Duggan A. (ed.) 2000, Nobles and Nobility: Concepts, Origins, Transformations, Woodbridge (SFK): Boydell \& Brewer, 101-113.

Calzona A. (ed.) 2008, Matilde e il tesoro dei Canossa tra castelli, monasteri e città. Catalogo della mostra (Reggio Emilia, 31 agosto 2008 - 11 gennaio 2009), Cinisello Balsamo (Milano): Silvana Editoriale.

Cammarosano P. 1998, Nobili e re. L'Italia politica dell'alto Medioevo, Roma-Bari: Laterza.

Capitani O. 1966, Immunità vescovili ed ecclesiologia in età pregregoriana e gregoriana. L'avvio alla restaurazione, Spoleto: CISAM.

-- 1984, L'Italia medievale nei secoli di trapasso: la riforma della chiesa (1012-1122), Bologna: Pàtron.

-- 1990, Tradizione ed interpretazione: dialettiche ecclesiologiche del sec. XI, Roma: Jouvence.

Cheyette F. L. 2001, Ermengarde of Narbonne and the World of the Troubadours, Ithaca (NY): Cornell University Press.

Cowdrey H.E.J. 1983, The Age of Abbot Desiderius: Montecassino, the Papacy and the Normans in the Eleventh and Early Twelfth Centuries, Oxford: Clarendon Press.

-- 1998, Pope Gregory VII: 1073-1085, Oxford: Clarendon Press.

Dockray-Miller M. 2015, The Books and the Life of Judith of Flanders, Farnham (SRY): 
Ashgate.

Duff N. 1909, Matilda of Tuscany: la gran donna d'Italia, London: Methuen \& Co.

Eads V. 2010, The Last Italian Expedition of Henry IV: Re-reading the Vita Mathildis of Donizone of Canossa, "Journal of Medieval Military History» 8, 23-68.

Glass D. 2010, The Sculpture of Reform in North Italy, ca. 1095-1130: History and Patronage of Romanesque Façades, Farnham (SRY): Ashgate.

Golinelli P. (ed.) 2003, I mille volti di Matilde: immagini di un mito nei secoli, Milano: Mondadori.

-- 2008, L'abbazia di Matilde. Arte e storia in un grande monastero dell'Europa benedettina. Catalogo della mostra San Benedetto Po, 31 agosto 2008 - 11 gennaio 2009, Bologna: Pàtron.

Hay D.J. 2008, The Military Leadership of Matilda of Canossa, 1046-1115, Manchester: Manchester University Press.

Healy P. 2005, Merito nominetur virago: Matilda of Tuscany in the polemics of the Investiture Contest, in Meek C., Lawless C. (eds.), Victims or Viragos, Dublin: Four Courts Press, 49-56.

Huddy M. E. 1906, Matilda, Countess of Tuscany, London: John Long. https://archive. org/details/matildacountesso00hudd

Lazzari T. 2006, Miniature e versi: mimesi della regalità in Donizone, in Isabella G. (ed.) 2006, Forme di potere nel pieno medioevo (secc. VIII-XII). Dinamiche e rappresentazioni, Bologna: CLUEB.

-- 2012, Goffredo di Lorena e Beatrice di Toscana, in Cantarella G.M., Calzona A. (eds.) 2012, La reliquia del sangue di Cristo. Mantova, l'Italia e l'Europa al tempo di Leone IX, Verona: Scripta, 225-242.

-- 2016, I poteri delle donne al tempo di Matilde, in Matilde di Canossa e il suo tempo: atti del XXI Congresso internazionale di studio sull'alto Medioevo in occasione del IX centenario della morte (1115-2015): San Benedetto Po - Revere - Mantova - Quattro Castella, 20-24 ottobre 2015, Spoleto: CISAM, 35-55.

Le Jan R. 2009, Mémoire, compétition et pouvoir. Le manuscrit de la Vie de Mathilde de Toscane (Vat. Lat. 4492), in Cottier J-F., Gravel M., Rossignol S. (eds.) 2009, Ad libros! Mélanges d'études médiévales offerts à Denise Angers et Joseph-Claude Poulin, Montréal: Les Presses de l'Université de Montréal, 105-120.

-- Memory, gift and politics: Matilda of Tuscany and her donations to St Peter, in Mélanges en l'honneur de Chris Wickham, in press.

Lo Prete K. A. 2007, Adela of Blois: Countess and Lord (c.1067-1137), Dublin: Four Courts Press.

-- 2014, 'The Lady Vanishes': Medieval Texts, Modern Historians and Lordly Women, "Quaestiones Medii Aevi Novae», 19, 55-110. 
Matilde di Canossa e il suo tempo 2016, Matilde di Canossa e il suo tempo, XXI Congresso internazionale di studio del CISAM (San Benedetto Po, Revere, Mantova, Quattro Castella, 20-24 ottobre 2015), Spoleto, CISAM.

Miccoli G. 1966, Chiesa gregoriana. Ricerche sulla Riforma del secolo XI, Firenze: La Nuova Italia.

Nell'VIII centenario di Matilde 1915, Nell'VIII centenario di Matilde di Canossa: 24 luglio 1915. Scritti varii, Reggio Emilia: Bassi.

Reynolds R.J. 2002, Reading Matilda: The Self-Fashioning of a Duchess, "Essays in Medieval Studies» 19 (1), 1-13.

Rinaldi R. 2003, Tra le carte di famiglia. Studi e testi canossani, Bologna: CLUEB.

Robinson I.S. 1978, Authority and Resistance in the Investiture Contest. The polemical literature of the late eleventh century, Manchester: Manchester University Press.

-- 1999, Henry IV of Germany, 1056-1106, Cambridge: Cambridge University Press.

Rough R.H. 1973, The Reformist Illuminations in the Gospels of Matilda, Countess of Tuscany. A Study in the art of the age of Gregory VII, The Hague: Nijhoff.

Salvarani R., Castelfranchi L. (eds.) 2008, Matilde di Canossa il papato l'impero. Storia, arte, cultura alle origini del romanico, Cinisello Balsamo (MI): Silvana Editoriale.

Sergi G. 1995, I confini del potere. Marche e signorie fra due regni medievali, Torino: Einaudi.

Spike M.K. 2004, Tuscan Countess. The life and extraordinary times of Matilda of Canossa, New York: Vendome Press.

Stiegemann C., Wemhoff M. (eds.) 2006, Canossa 1077. Erschütterung der Welt. Geschichte, Kunst und Kultur am Anfang der Romanik, München: Hirmer.

Verzar C. 2010, Picturing Matilda of Canossa: Medieval Strategies of Representation, in Maxwell R. A (ed.) 2010, Representing History, 900-1300, University Park (PA): Pennsylvania State University Press, 73-90. 